\title{
Traumatic Injury to the Immature Brain: Inflammation, Oxidative Injury, and Iron-Mediated Damage as Potential Therapeutic Targets
}

\author{
Mathew B. Potts, ${ }^{*}$ Seong-Eun Koh,* William D. Whetstone, ${ }^{\dagger}$ Breset A. Walker, ${ }^{\dagger}$ \\ Tomoko Yoneyama, ${ }^{*}$ Catherine P. Claus, ${ }^{*}$ Hovhannes M. Manvelyan, ${ }^{*}$ and \\ Linda J. Noble-Haeusslein* \\ Departments of ${ }^{*}$ Neurological Surgery and ${ }^{\dagger}$ Medicine (Division of Emergency Medicine), University of California, \\ San Francisco, California 94143
}

\begin{abstract}
Summary: Traumatic brain injury (TBI) is the leading cause of morbidity and mortality among children and both clinical and experimental data reveal that the immature brain is unique in its response and vulnerability to TBI compared to the adult brain. Current therapies for pediatric TBI focus on physiologic derangements and are based primarily on adult data. However, it is now evident that secondary biochemical perturbations play an important role in the pathobiology of pediatric TBI and may provide specific therapeutic targets for the treatment of the head-injured child. In this review, we discuss three specific components of the secondary pathogenesis of pediatric TBI inflammation, oxidative injury, and iron-induced damage - and potential therapeutic strategies associated with each. The in-
\end{abstract}

flammatory response in the immature brain is more robust than in the adult and characterized by greater disruption of the blood-brain barrier and elaboration of cytokines. The immature brain also has a muted response to oxidative stress compared to the adult due to inadequate expression of certain antioxidant molecules. In addition, the developing brain is less able to detoxify free iron after TBI-induced hemorrhage and cell death. These processes thus provide potential therapeutic targets that may be tailored to pediatric TBI, including anti-inflammatory agents such as minocycline, antioxidants such as glutathione peroxidase, and the iron chelator deferoxamine. Key Words: Traumatic brain injury, immature brain, inflammation, oxidative damage, iron.

\section{INTRODUCTION}

Traumatic brain injury (TBI) is a leading cause of morbidity and mortality among children and adolescents. In the United States alone, there are an estimated 475,000 annual cases of TBI among children under the age of 15 years, resulting in 2,685 deaths. ${ }^{1}$ The disabilities resulting from pediatric TBI are often profound and life-long, ${ }^{2}$ and include sensorimotor ${ }^{3}$ and cognitive impairments ${ }^{4}$ as well as psychological dysfunction. ${ }^{4}$

TBI is defined as any head injury with traumatic etiology, including blunt or penetrating trauma and nonaccidental injury. Falls, motor vehicle accidents, and abuse account for the majority of injuries in children under four years of age, while motor vehicle accidents

Corresponding Author: Linda J. Noble-Haeusslein, 521 Parnassus Ave, Room C-224, San Francisco, CA 94143-0520, Phone: 415-4764850, Fax: 415-476-5634. E-mail: noblelj@itsa.ucsf.edu. are most common among older children. ${ }^{5}$ The primary injury may manifest as diffuse axonal injury, intraparenchymal contusions, intracranial hematomas, skull fractures, and combinations thereof. ${ }^{6}$ This mechanical injury is often followed by secondary physiologic and biochemical derangements that generate further damage.

Pediatric versus adult TBI. Although there are similarities between head injury in the developing and adult brains, pediatric brain injury poses unique challenges. In general, the primary injury is more often diffuse in the child due to a greater head-to-torso ratio and brain-water content. $^{2}$ Clinical $^{2,7,8}$ and experimental ${ }^{9}$ studies demonstrate that the developing brain may also be more vulnerable to traumatic injury than the adult brain. Such vulnerability mandates that the head-injured child must be viewed and treated differently than the head-injured adult. $^{10}$

Age-dependent variation. Adding to this challenge is the considerable age-dependent variation that exists 
within the pediatric population. The developmental processes of myelination, ${ }^{11}$ neuronal pruning, ${ }^{12}$ axonal growth, ${ }^{13}$ and synaptic reorganization ${ }^{12}$ may continue for years after birth. Standard physiologic measurements such as intracranial pressure, mean arterial pressure, and cerebral perfusion pressure also vary with age. ${ }^{10,14}$ For these reasons, it is perhaps not surprising that the developing brain exhibits age-dependent vulnerability to TBI, with children under four years of age showing the greatest vulnerability as evidenced by more profound cognitive and motor deficits. ${ }^{15}$

Current acute management of severe pediatric TBI. Management of the head-injured child aims to avoid, anticipate, and actively treat secondary brain insults. Adelson et al. ${ }^{10}$ have recently published evidencebased guidelines that establish what is known about the acute management of pediatric TBI ranging from trauma systems and pre-hospital management to measurement and manipulation of physiologic variables, nutritional support, and prophylaxis of seizures. These guidelines provide a unified basis from which physicians can make management decisions. They also serve as a foundation from which to direct future research, thus facilitating the advancement of the field of pediatric neurotrauma.

\section{Determinants of recovery}

Recovery is determined by the magnitude of the primary mechanical insult, characterized by shearing and tearing of neural and vascular structures, and by physiologic and biochemical pathogenic events that progressively compromise otherwise intact tissue. Physiologic events associated with TBI, including hypotension, ${ }^{16}$ hypoxia, ${ }^{16}$ hyperthermia $\left(>38.5^{\circ} \mathrm{C}\right),{ }^{17}$ elevated intracranial pressure, ${ }^{10}$ and posttraumatic seizures, ${ }^{10}$ adversely affect outcome in brain-injured children. Biochemical perturbations associated with inflammation, oxidative stress, toxic metabolites, excitotoxicity, and apoptosis may likewise impair brain function. ${ }^{18,19}$

The challenge in advancing the field of pediatric neurotrauma will be to develop therapies that are specifically tailored to the maturational state of the brain. In that context, secondary pathogenic events are a promising target of current novel therapies and research. In this review, we focus on three major secondary events that likely influence outcome after brain injury - inflammation, oxidative injury, and iron-mediated damage - and we consider potential therapeutic interventions in the context of each of these events.

\section{Inflammation and brain injury}

There is growing evidence that inflammation is critical to both secondary injury and repair mechanisms in the central nervous system. Here we consider the complex interplay between inflammatory events and early secondary pathogenesis.
Characterization of inflammation. The hallmarks of early inflammation in the brain include activated microglia, the presence of neutrophils, and edema. Microglia act as immune reactive surveillance cells and are integral to the detection of pathogens, host defense, and tissue repair. ${ }^{20}$ Of the variety of cytotoxic factors released by microglia, reactive oxygen species such as the superoxide free radical are thought to play a role in inflammation-mediated damage to neurons. ${ }^{21}$ Neutrophils can likewise promote early pathogenesis, including brain swelling, ${ }^{22}$ through the release of free radicals, proteases, and proinflammatory cytokines. ${ }^{23-25}$

Modulators of early inflammation. An acute inflammatory response, which involves the integrated activities of cytokines, chemokines, and vascular adhesion molecules, contributes to the pathophysiology of TBI including vascular dysfunction and cell injury. ${ }^{26-28}$ Cytokines are multifunctional peptides that act as pro-inflammatory molecules. Many cytokines, including NF- $\kappa \mathrm{B}$, TNF- $\alpha$, IL- $1 \beta$, IL-6, and IL-10, are induced in response to TBI. ${ }^{26,27,29-35}$ Bell et al. ${ }^{36}$ measured IL-6 in the cerebrospinal fluid of infants and children with severe TBI and found a 60 -fold increase over controls. This level was similar to that seen in the serum of infants and children with septic shock, ${ }^{37}$ demonstrating the magnitude of inflammation in the injured immature brain. Although these cytokines are implicated in early pathogenesis, there is increasing evidence for more complex roles in neuronal injury and survival that may depend upon their concentrations as well as the timing of their expression after injury. ${ }^{27}$

Chemokines are known for their roles in leukocyte communication and migration. ${ }^{38}$ They comprise a family of structurally related cytokines that activate and direct leukocyte traffic. ${ }^{38}$ Interleukin-8 (IL-8), a chemokine in humans, modulates chemotaxis of neutrophils. Several lines of evidence implicate IL- 8 as a mediator of inflammation in the injured brain. Direct injection of IL-8 into the murine brain results in marked neutrophil recruitment, coincident with disruption of the blood-brain barrier. ${ }^{39}$ Moreover, clinical studies have demonstrated a significant elevation of IL-8 in the cerebrospinal fluid of severely brain-injured children. ${ }^{29,40}$

Cyclooxygenase (COX or prostaglandin $\mathrm{H}$ synthase) is the obligate, rate-limiting enzyme for the conversion of arachidonic acid into prostaglandins. Prostaglandins are among the pivotal mediators and modulators of inflammation and, together with thromboxanes, are part of the prostanoid family that are synthesized from arachidonic acid $\left(5,8,11,14\right.$-eicosatetraenoic acid) via COX. ${ }^{41}$ Two COX enzymes have been identified: the constitutively expressed COX-1 and the inducible, highly regulated COX-2. Widely used to treat chronic inflammatory 
TABLE 1. Examples of anti-inflammatory therapeutic agents that have been tested in models of TBI

\begin{tabular}{|c|c|c|c|}
\hline Therapeutic agent & Target/Effect & Functional Outcome & References \\
\hline Progesterone & $\begin{array}{l}\text { Reduces cytotoxic surge; decreases } \\
\text { TNF- } \alpha \text { and IL- } 1 \beta\end{array}$ & - & $\begin{array}{l}\text { Pettus, } 2005^{141} \\
\mathrm{He}, 2004^{142}\end{array}$ \\
\hline Allopregnanolone & Decreases TNF- $\alpha$ and IL- $1 \beta$ & 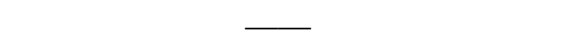 & $\mathrm{He}, 2004^{142}$ \\
\hline Hypothermia & $\begin{array}{l}\text { Alters regulation of specific genes } \\
\text { involved in delayed } \\
\text { inflammation }\end{array}$ & $\longrightarrow$ & Treuttner, $2005^{143}$ \\
\hline Apo-E & $\begin{array}{l}\text { Decreases TNF- } \alpha \text { mRNA and } \\
\text { oxidative stress }\end{array}$ & $\begin{array}{l}\text { Improves vestibulomotor (Rotorod) and } \\
\text { cognitive (Morris water maze) } \\
\text { function }\end{array}$ & Lynch, $2005^{144}$ \\
\hline $\begin{array}{l}\text { Monoclonal } \\
\text { antibodies } \\
\text { against } \\
\text { cytokines IL-6 } \\
\text { and TNF- } \alpha\end{array}$ & No effect on brain water content & $\begin{array}{l}\text { No effect on cognitive (Morris water } \\
\text { maze) or motor function }\end{array}$ & Marklund, $2005^{145}$ \\
\hline Minocycline & Decreases IL- $1 \beta$ & 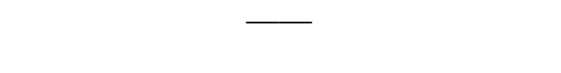 & $\begin{array}{l}\text { Sanchez Mejia, } \\
2001^{57}\end{array}$ \\
\hline $\begin{array}{l}\text { Cyclooxygenase- } \\
2 \text { inhibitor }\end{array}$ & $\begin{array}{l}\text { Attenuates prostaglandin- } \mathrm{E}_{2} \text { and } \\
\text { activated caspase- } 3 \text { expression }\end{array}$ & $\begin{array}{l}\text { Improves reflexes and cognitive } \\
\text { function (Morris water maze) }\end{array}$ & Gopez, $2005^{146}$ \\
\hline
\end{tabular}

disorders, COX inhibitors have shown promise in attenuating inflammation associated with brain injury. ${ }^{42}$

Adhesion molecules are integral to leukocyte transmigration, a process that involves the binding of selectins, which are expressed on activated endothelium, to ligands present on leukocytes. ${ }^{43}$ This binding promotes leukocytic rolling with subsequent attachment to intercellular adhesion molecule-1 (ICAM-1) and vascular adhesion molecule-1 (VCAM-1), which are present on the endothelium. This attachment is a necessary first step in the transmigration of leukocytes across the endothelial cell. Both ICAM-1 and VCAM-1 are upregulated in the traumatized adult brain. ${ }^{44-46}$ Moreover, there is a correlation between elevated levels of ICAM-1, severity of injury, and neurologic outcome in clinical studies of head injury in children. ${ }^{47}$

Inflammation and the developing brain: "Window of susceptibility". The kinetics of leukocyte recruitment during acute inflammation vary according to age. Adult mice are more resistant to inflammation than are one to three week old mice, as evidenced by less leukocyte recruitment and barrier disruption in response to cytokines. ${ }^{48,49}$ The biologic basis for this age-related "window of susceptibility" is not clear. There is evidence that marked neutrophil infiltration and barrier disruption seen in the young brain may reflect increased susceptibility to the neutrophil chemoattractive effects of chemokines. ${ }^{50}$

Inflammation as a target for therapeutic intervention. With inflammation playing such an important role in the pathophysiology of TBI, it is a logical step to consider anti-inflammatory agents as potential therapies for TBI (Table 1). We focus here on minocycline, a tetracycline derivative, because of its broad application to various models of brain injury. Minocycline has generated much interest as a modifier of acute and chronic neuroinflammation and for its ability to reduce neuronal apoptosis. The drug was originally found to attenuate the delayed phase of injury after transient cerebral ischemia by reducing microglial activation and proliferation. ${ }^{51,52}$ Minocycline likewise modulates neuroinflammation in animal models of multiple sclerosis, ${ }^{53}$ Huntington's disease ${ }^{54}$ and amyotrophic lateral sclerosis. ${ }^{55}$ Its action is exerted at least in part through inhibition of mitogenactivated protein kinase $\mathrm{p} 38$, a stress-activated protein kinase that mediates the production of other inflammatory mediators. ${ }^{56}$ The beneficial effects of minocycline are not limited to its ability to reduce inflammation, however. Minocycline also targets neuronal apoptosis by inhibiting caspase- $1^{57}$ and caspase- $3 .^{58}$

As with the adult brain, minocycline protects against injury in the immature brain. ${ }^{58}$ However, unlike in the adult, this protection is not sustained over time. ${ }^{59}$ Such findings serve to emphasize the unique response of the developing brain to injury and remind us that the neuroprotective effects of a particular drug in the injured adult brain may not be predictive of its action in the immature brain. Any potential therapeutic agent must therefore be carefully evaluated in this context. Furthermore, minocycline is known to cause tooth discoloration and affect bone growth in young children, demonstrating that any potential therapeutic agent may have adverse developmental effects. This collective experience with minocycline highlights an important point; screening of candidate anti-inflammatory agents should be done in ageappropriate models of injury with the understanding that their actions may vary according to the nature of the injury and the molecular specificity of their targets. 


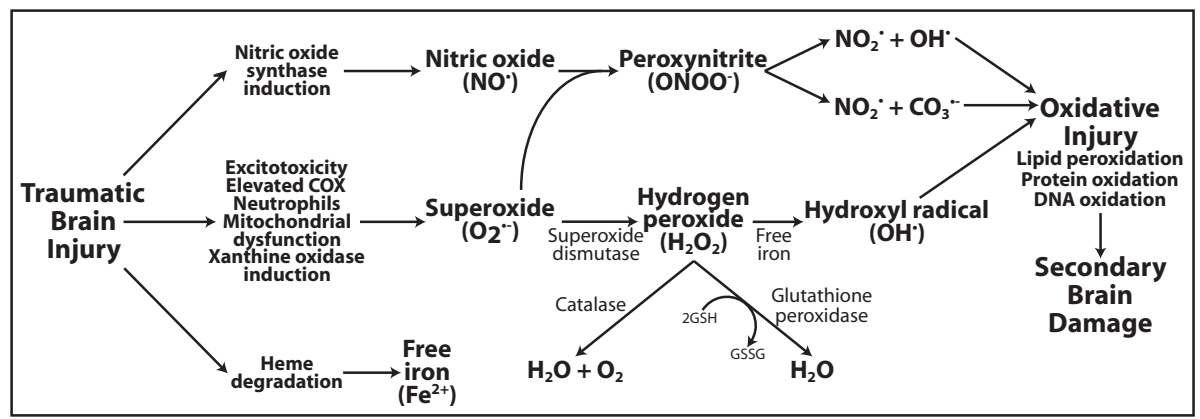

FIG. 1. Oxidative injury cascade after TBI. TBI-induced oxidative damage begins with the production of superoxide and nitric oxide. These two molecules combine to form peroxynitrite, which leads to the production of multiple damaging free radicals, including nitrogen dioxide $\left(\mathrm{NO}_{2}{ }^{\circ}\right)$, the carbonate radical $\left(\mathrm{CO}_{3}{ }^{\bullet-}\right)$, and the hydroxyl radical $\left(\mathrm{OH}^{\circ}\right)$. Superoxide is also converted to hydrogen peroxide by the enzyme superoxide dismutase. Under normal physiologic conditions, hydrogen peroxidase is cleared by the enzymes catalase and glutathione peroxidase, which convert it to water and oxygen. In the presence of free iron, however, hydrogen peroxide can be metabolized to the hydroxyl radical. Together, these TBI-induced free radicals lead to oxidative damage and secondary brain injury. COX = cyclooxygenase; GSH = glutathione; GSSG = glutathione disulfide.

\section{Oxidative damage}

Oxidative damage is a significant component of the secondary injury cascade that accompanies TBI (Figure 1). ${ }^{60-64}$ Such injury is mediated by reactive oxygen and nitrogen species, including the superoxide ion, hydrogen peroxide, hydroxyl radical, nitric oxide, and peroxynitrite, ${ }^{61,63,65}$ Glutamate-mediated excitotoxicity, which leads to an increase in intracellular calcium, induces several endogenous enzymes that produce free radicals, including nitric oxide synthase, xanthine oxidase, and the phospholipase $\mathrm{A}_{2}$-cyclooxygenase pathway. ${ }^{63}$ Such changes in intracellular calcium also perturb mitochondrial function, leading to leakage of superoxide. ${ }^{63,66}$ The release of free iron, as discussed in the following section, is likewise an important component of the oxidative damage cascade, catalyzing the formation of superoxide from free oxygen and the potent hydroxyl radical from hydrogen peroxide. ${ }^{61}$ Activated neutrophils can also directly produce superoxide ${ }^{63}$ and nitric oxide. ${ }^{61,67}$ Finally, free radicals react with one another to produce additional free radicals such as peroxynitrite, which is generated from the reaction between superoxide and nitric oxide. ${ }^{61}$

Several endogenous antioxidant compounds exist that prevent oxidative damage under physiologic conditions (Figure 1). Superoxide dismutase (SOD) catalyzes the conversion of superoxide to hydrogen peroxide. Glutathione peroxidase (GPx) and catalase then clear hydrogen peroxide, forming molecular oxygen and water. Free radical scavengers, collectively known as low molecular weight antioxidants, are also found in the brain. These include the endogenous molecules glutathione, melatonin, uric acid, and histidine-related compounds as well as exogenous molecules such as tocopherols (vitamin E), ascorbic acid, and lipoic acid, which are obtained from the diet. ${ }^{64}$ After TBI, these antioxidant defense mechanisms can become overwhelmed, leading to cellular damage and death via free radical-mediated lipid peroxidation and protein and DNA oxidation. ${ }^{61,63,65,68}$ The brain is especially susceptible to such oxidative damage due to its high fatty acid content and proportionately large share of total body oxygen consumption. ${ }^{69}$ This vulnerability is further compounded in the immature brain by a reduced antioxidant reserve. Bayir et al. ${ }^{70}$ assessed measures of oxidative stress and total antioxidant reserve in the cerebrospinal fluid of head-injured infants and children and demonstrated a reduction in total antioxidant reserve compared to controls as well as a depletion of the antioxidant compounds ascorbic acid and glutathione. Such findings may be due to the regulation of antioxidant enzymes during brain development and maturation. ${ }^{71}$ For example, metallothioneins, compounds that act as both free radical scavengers and metal chelators, are expressed at lower levels in the immature brain than in the adult and their level of expression inversely correlates with neuronal degeneration after cortical ablation injury. ${ }^{72}$ Similarly, certain SOD isoforms are known to be expressed at lower levels in the immature brain. ${ }^{73}$

Superoxide dismutase. Three human isoforms of SOD exist. Copper-zinc SOD (SOD1) is predominately located within the cytosol and lysosomes of cells and is perhaps the most studied of the SOD isoforms in brain injury. Increased activity of SOD1 is associated with neuroprotection in the injured, adult brain. This is best exemplified in transgenic mice that overexpress SOD1, where there is reduced cerebral edema, tissue necrosis, and disruption of the blood-brain barrier along with an improvement in functional recovery after TBI as compared to wildtype controls. ${ }^{74,75}$ Similar neuroprotection is seen in these adult transgenic mice when subjected to focal ischemic brain injury. ${ }^{76}$ Despite these findings, there is currently no evidence that SOD1 overexpression confers neuroprotection in the immature brain after TBI. In fact, at least in experimental models of neonatal hypoxia/ischemia, SOD1 overexpression exacerbates injury. ${ }^{77}$ This adverse response has been attributed to 
inadequate antioxidant reserves in the immature brain leading to an accumulation of hydrogen peroxide. ${ }^{78} \mathrm{Hy}-$ drogen peroxide itself is especially toxic to immature neurons ${ }^{79}$ and in the presence of free metals, can be further metabolized to the hydroxyl radical. GPx and catalase limit this toxicity by catalyzing the reduction of hydrogen peroxide to water. The efficacy of superoxide dismutase is thus dependent upon these two downstream antioxidants to eliminate hydrogen peroxide.

A second SOD isoform, manganese SOD (SOD2), is most prevalent within mitochondria. Mice deficient in SOD2 show an increased release of mitochondrial cytochrome c after TBI that is associated with greater necrotic cell death within the cortical lesion. ${ }^{80}$ Extracellular SOD (SOD3), the third SOD isoform, has not been studied in TBI. However, its overexpression has been shown to be beneficial in models of cerebral ischemia, ${ }^{81,82}$ while mice deficient in this enzyme are more vulnerable to ischemic injury. ${ }^{83}$

Pharmacologic variants of SOD have also shown some efficacy in experimental models of TBI. These variants have been generated to increase the blood brain barrier permeability of SOD and thus improve its efficacy. Polyethylene glycol-conjugated SOD (PEG-SOD, pegorgotein) has been shown to improve post-injury motor deficits, but has no effect on balance or spatial memory deficits. ${ }^{84}$ Another variant, lecithinized SOD, decreases edema and improves survival. ${ }^{85}$ Interestingly, while PEG-SOD showed no effect on cognitive function, lecithinized SOD decreases neuronal loss in the hippocampal CA3 region, ${ }^{86}$ which is associated with spatial memory. ${ }^{87}$

Glutathione peroxidase. GPx is likely more important than catalase in eliminating hydrogen peroxide and in contributing to the increased vulnerability of the immature brain to injury. GPx activity in the brain is sevenfold higher than that of catalase ${ }^{88}$ and its expression is more ubiquitous. ${ }^{65}$ Although GPx is upregulated in the adult brain after TBI, no such upregulation occurs in the immature brain. ${ }^{89}$ Similarly, GPx expression actually decreases in the neonatal brain after hypoxia/ischemia while catalase activity remains unchanged. ${ }^{78}$ This inability of the immature brain to respond to injury by upregulating GPx may therefore play a role in the vulnerability of the immature brain to injury. In addition, overexpression of GPx in a model of hypoxia/ischemia improves outcome, ${ }^{71}$ suggesting that this antioxidant enzyme has great promise as a potential therapeutic agent for pediatric TBI.

Other antioxidant compounds. Although a thorough discussion is beyond the scope of this review, many other agents with antioxidant properties have been studied and shown benefits in models of TBI. ${ }^{64,75,90}$ These include nitrone spin traps, ${ }^{91} 21$-aminosteroid compounds (most notably tirilazad mesylate), ${ }^{92-95}$ cyclooxygenase inhibi- tors (eg. ibuprofen and indomethacin), ${ }^{96-98}$ nitric oxide synthase inhibitors, ${ }^{99}$ tocopherols, ${ }^{100,101}$ nitroxide radicals, ${ }^{102,103}$ melatonin, ${ }^{104,105}$ and the non-psychoactive cannabinoid dexanabinol. ${ }^{106,107}$ Multiple other novel antioxidants also exist. ${ }^{108-111}$ Unfortunately, only one of these promising compounds, melatonin, has been tested in a model of TBI in the immature brain, where it attenuates hippocampal neuronal cell death and improves spatial memory function. ${ }^{105}$

Human studies. Despite such compelling experimental evidence, clinical trials using antioxidants in TBI have been less successful. A phase II clinical trial in which PEG-SOD was administered intravenously to adults within twelve hours after severe head injury demonstrated an improvement in three- and six-month mortality and functional outcome (as measured by the Glasgow Outcome Scale) in patients receiving the highest dose of PEG-SOD $(10,000 \mathrm{U} / \mathrm{kg}){ }^{112}$ However, when further tested in a phase III randomized controlled trial, no statistical difference in mortality or outcome at three months post-injury was found between controls and patients receiving either $10,000 \mathrm{U} / \mathrm{kg}$ or $20,000 \mathrm{U} / \mathrm{kg}$ of PEG-SOD. ${ }^{113}$ The free radical scavenger tirilazad mesylate also failed to show any benefit over placebo in a randomized controlled trial of adults with severe and moderate TBI with the exception of males presenting with a subarachnoid hemorrhage. ${ }^{114}$ In this group, tirilazad mesylate treatment significantly reduced mortality at six months post-injury. Dexanabinol, a synthetic cannabinoid with antioxidant, anti-inflammatory, and antiglutamatergic properties, has also undergone phase II testing in severe TBI patients. ${ }^{115}$ Patients receiving this drug showed improvements in initial intracranial pressure, cerebral perfusion pressure, and systolic blood pressure, with a trend towards improved six-month outcome. These results have led to a phase III trial that is currently ongoing. Unfortunately, no clinical trials have been conducted in head-injured children, in whom experimental data suggest antioxidant therapies may have the greatest effects.

Interestingly, ebselen, an antioxidant compound with properties that mimic GPx, has been tested clinically in adult patients with both ischemic and hemorrhagic stroke. ${ }^{116-118}$ In a randomized controlled trial of patients with ischemic stroke, those who received ebselen treatment within 24 hours after their stroke had significantly better functional outcomes one month later. ${ }^{116}$ Similarly, in a randomized controlled study of patients with aneurysmal subarachnoid hemorrhage, ebselen treatment led to improved functional outcomes at three months in patients diagnosed with delayed ischemic neurologic deficits. ${ }^{117}$ A third randomized controlled trial of patients with complete occlusion of the middle cerebral artery also showed benefits from ebselen treatment. ${ }^{118}$ With such clinical successes in addition to laboratory evidence 

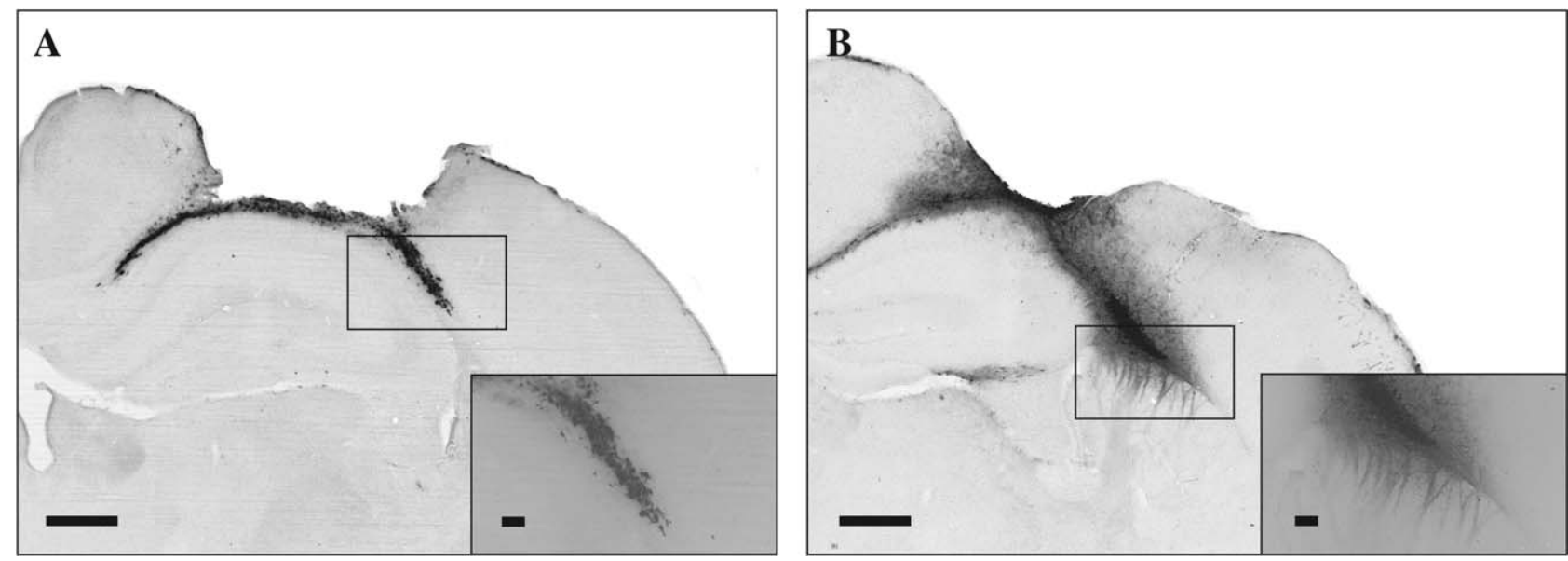

FIG. 2. Iron accumulation in the immature brain after TBI. Perls' stain for iron $\left(\mathrm{Fe}^{3+}\right)$ supplemented by $3,3^{\prime}$-diaminobenzidine to illustrate iron accumulation and distribution in the immature brain (injured at postnatal day 21). The ipsilateral hemisphere is shown at 7 (A) and 14 (B) days after TBI. Iron is localized in both cells (A) and fiber tracts (B) associated with the external capsule. Main image scale bars $=500 \mu \mathrm{m}$; inset scale bars $=50 \mu \mathrm{m}$.

suggesting that GPx is a vital factor in the vulnerability of the immature brain to TBI, ebselen should be strongly considered as a potential therapy in pediatric TBI.

\section{Iron accumulation in the injured brain}

Degradation products of heme, and in particular free iron, are important sources of oxidative stress in the traumatized brain. ${ }^{119}$ Iron reacts with hydrogen peroxide to form hydroxyl radicals (Figure 1) and with lipids to generate alkoxy and peroxy radicals. As discussed in the previous section, the immature brain may be especially vulnerable to the adverse effects of oxidative stress, making iron a potential target for therapy after trauma to the immature brain.

Iron regulation during normal development. Iron and its regulatory proteins play a critical role in development and are likely important in defining the selective vulnerability of the developing brain to traumatic injury. Iron is necessary for growth and cellular differentiation due to its role as a constituent of molecules generating mitochondrial energy, such as cytochrome c. ${ }^{120}$ Iron regulation is partly governed by transferrin, a transport protein, and ferritin, a storage protein. ${ }^{120}$ These two molecules bind iron when it is not a component of ironcontaining moieties such as hemoglobin, myoglobin, and cytochrome molecules. Transferrin and ferritin are thus important in limiting the cytotoxic effects of iron. The concentrations of these binding proteins change throughout early development before reaching adult levels. ${ }^{121}$ Such age-dependent variation may be a determinant of cellular vulnerability to iron accumulation. Free iron is found in the plasma of normal term and preterm neonates, indicating that the binding capacity of transferrin is saturated in the immature brain. ${ }^{122-124}$ This coincides with a low concentration of transferrin in the cerebrospinal fluid of these children. ${ }^{124}$
Iron accumulation after injury to the developing brain. Iron accumulates in the developing brain after $\mathrm{TBI}^{119}$ (Figure 2). However, it is unclear how such accumulation may modulate pathogenesis. Findings in models of hypoxia/ischemia may offer important insight into the heightened vulnerability of the immature brain to traumatic injury. There is increased iron deposition in subcortical regions and white matter of children with severe ischemia. ${ }^{125}$ Similarly, there is excess iron deposition after experimental hypoxia/ischemia in the immature rodent. ${ }^{126}$ The magnitude of iron accumulation is likely age-dependent. Iron rapidly accumulates in the immature brain after hypoxia/ischemia ${ }^{127}$ in contrast to a more delayed accumulation in the adult brain. ${ }^{128}$

Damaging effects of iron. Exposure of the neonatal brain to abnormally high levels of iron leads to cognitive and motor deficits manifested in adulthood. ${ }^{129}$ On a cellular level, iron relocalizes from microglia to oligodendrocytes during normal maturation. ${ }^{130}$ Furthermore, after hypoxia/ischemia, the localization of iron reverts to microglia. The sequestration of iron by microglia may therefore limit its availability to oligodendrocytes, resulting in impaired myelination. ${ }^{126}$ This change in iron localization is possibly due to the fact that ferritin expression is delayed in oligodendrocytes in the injured immature brain. ${ }^{126,131}$

Iron chelation - a possible therapy? Pharmacologic approaches to chelate iron have been important in understanding its pathogenicity after TBI. Several iron chelators have been investigated, including those that target either intracellular free iron, extracellular free iron, or both. ${ }^{132}$ In a cold-induced model of brain injury, 2,3dihydroxybenzoic acid, an extracellular ferric iron chelator, 2,2-bipyridine, an intracellular ferrous iron chelator, and deferoxamine, an intracellular and extracellular 
ferric iron chelator, were evaluated for their roles in brain edema and blood brain barrier disruption. ${ }^{132}$ Only the 2,2-bipyridine- and deferoxamine-treated groups demonstrated significantly reduced edema and blood-brain barrier disruption. Deferoxamine is the most widely investigated iron-chelator in the setting of brain injury and it offers neuroprotection through multiple mechanisms. Deferoxamine scavenges ferric iron as well as the hydroxyl radical and the peroxynitrite anion. It attenuates oxidative stress in cultured neurons and astrocytes, likely a result of reducing the amount of iron available to generate free radicals. ${ }^{133}$ It may also confer added protection to the injured immature brain by upregulating hypoxia-inducible factor- 1 , which promotes cell survival via the activation of molecules such as erythropoetin and vascular endothelial growth factor. ${ }^{134}$ This later phenomenon is supported in a recent in vitro study of ischemic injury where the beneficial effects of deferoxamine in reducing hippocampal neuronal death were diminished in the presence of an antisense oligonucleotide specific for hypoxia-inducible factor-1alpha. ${ }^{135}$

Deferoxamine has also been studied in vivo. After TBI in the adult rodent, deferoxamine treatment improves behavioral motor recovery by attenuating injury. ${ }^{136,137}$ It has also been shown to reduce brain edema ${ }^{138}$ and improve motor recovery ${ }^{136-138}$ in experimental models of TBI ${ }^{136,137}$ and intracerebral hemorrhage. ${ }^{138}$ Additionally, in large animal models of hypoxic/ischemic injury in the immature brain, deferoxamine reduces free iron levels, preserves cerebral energy metabolism and electrical brain activity, and attenuates edema. ${ }^{139,140}$ With such compelling evidence for the beneficial effects of iron chelation in varying types of brain injury, deferoxamine, or a similar compound, is a prime therapeutic candidate for the treatment of TBI in children.

\section{CONCLUSION}

Relative to adult TBI, our understanding of and ability to medically manage pediatric TBI is still in its infancy. We must begin by developing a better understanding of those factors that govern injury and repair processes in the context of brain maturation. Here we consider three specific therapeutic targets based upon what is currently known about the unique vulnerability of the developing brain to injury - inflammation, oxidative injury, and iron-mediated damage. Selective blockade of these pathobiologic events in the acutely injured brain may not only promote tissue sparing but may also define a wound healing environment that acts synergistically with developmental processes to restore function.

Several issues emerge from this review. First, there are likely to be pathobiologic events that are common to brain injury in both the adult and immature brain.
Nevertheless, successful targeting of these events in the adult brain may not be predictive of similar success in the immature brain where there may be broader developmental consequences. Thus, neurotherapeutic candidates should be stringently evaluated in the context of development. Second, although there is an ongoing effort to standardize and improve the clinical management of the brain-injured child, advances in targeted therapeutic interventions are limited in scope. Therefore, there is much to be gained by developing and characterizing novel agents in age-appropriate models of TBI. To expedite clinical trials, it is also important to consider therapeutic agents, such as deferoxamine, that are currently approved for use in humans and have the potential of reaching human trials and widespread use much more rapidly.

Finally, the pathogenesis of TBI should be considered in a more enduring context where aberrant tissue remodeling and disruption of normal developmental processes impede recovery. Thus, the long-term treatment of TBI should entail a multidisciplinary approach, where pharmacotherapy is merged with sensorimotor and cognitive neurorehabilitation to maximize recovery of function in the brain-injured child.

Acknowledgments: This research supported by $\mathrm{NIH}$ RO1NS50159 and the UCLA Neurotrauma Initiative.

\section{REFERENCES}

1. Langlois J, Rutland-Brown W, Thomas K: Traumatic brain injury in the United States: Emergency department visits, hospitalizations, and deaths. Atlanta (GA): Centers for Disease Control and Prevention, National Center for Injury Prevention and Control, 2004.

2. Mazzola CA, Adelson PD. Critical care management of head trauma in children. Crit Care Med 30:S393-401, 2002.

3. Costeff H, Groswasser Z, Goldstein R. Long-term follow-up review of 31 children with severe closed head trauma. J Neurosurg 73:684-687, 1990.

4. Salmond CH, Sahakian BJ. Cognitive outcome in traumatic brain injury survivors. Curr Opin Crit Care 11:111-116, 2005.

5. Levin HS, Aldrich EF, Saydjari C, Eisenberg HM, Foulkes MA, Bellefleur M, et al. Severe head injury in children: experience of the Traumatic Coma Data Bank. Neurosurgery 31:435-443; discussion 443-434, 1992.

6. Khoshyomn S, Tranmer BI. Diagnosis and management of pediatric closed head injury. Semin Pediatr Surg 13:80-86, 2004.

7. Adelson PD, Clyde B, Kochanek PM, Wisniewski SR, Marion DW, Yonas H. Cerebrovascular response in infants and young children following severe traumatic brain injury: a preliminary report. Pediatr Neurosurg 26:200-207, 1997.

8. Koskiniemi M, Kyykka T, Nybo T, Jarho L. Long-term outcome after severe brain injury in preschoolers is worse than expected. Arch Pediatr Adolesc Med 149:249-254, 1995.

9. Bittigau P, Sifringer M, Felderhoff-Mueser U, Ikonomidou C. Apoptotic neurodegeneration in the context of traumatic injury to the developing brain. Exp Toxicol Pathol 56:83-89, 2004.

10. Adelson PD, Bratton SL, Carney NA, Chesnut RM, du Coudray HE, Goldstein B, et al. Guidelines for the acute medical management of severe traumatic brain injury in infants, children, and adolescents. Pediatr Crit Care Med 4:S2-75, 2003.

11. Carmody DP, Dunn SM, Boddie-Willis AS, DeMarco JK, Lewis 
M. A quantitative measure of myelination development in infants, using MR images. Neuroradiology 46:781-786, 2004.

12. Koizumi $\mathrm{H}$. The concept of 'developing the brain': a new natural science for learning and education. Brain Dev 26:434-441, 2004.

13. Haynes RL, Borenstein NS, Desilva TM, Folkerth RD, Liu LG, Volpe JJ, et al. Axonal development in the cerebral white matter of the human fetus and infant. J Comp Neurol 484:156-167, 2005.

14. Chambers IR, Jones PA, Lo TY, Forsyth RJ, Fulton B, Andrews $\mathrm{PJ}$, et al. Critical thresholds of intracranial pressure and cerebral perfusion pressure related to age in paediatric head injury. $\mathrm{J} \mathrm{Neu}$ rol Neurosurg Psychiatry, 2005.

15. Durkin MS, Olsen S, Barlow B, Virella A, Connolly ES, Jr. The epidemiology of urban pediatric neurological trauma: evaluation of, and implications for, injury prevention programs. Neurosurgery 42:300-310, 1998.

16. Pigula FA, Wald SL, Shackford SR, Vane DW. The effect of hypotension and hypoxia on children with severe head injuries. J Pediatr Surg 28:310-314; discussion 315-316, 1993.

17. Natale JE, Joseph JG, Helfaer MA, Shaffner DH. Early hyperthermia after traumatic brain injury in children: risk factors, influence on length of stay, and effect on short-term neurologic status. Crit Care Med 28:2608-2615, 2000.

18. Ylvisaker M, Adelson PD, Braga LW, Burnett SM, Glang A, Feeney T, et al. Rehabilitation and ongoing support after pediatric TBI: twenty years of progress. J Head Trauma Rehabil 20:95109, 2005

19. Bayir H, Kochanek PM, Clark RS. Traumatic brain injury in infants and children: mechanisms of secondary damage and treatment in the intensive care unit. Crit Care Clin 19:529-549, 2003.

20. Kreutzberg G. Microglia: a sensor for pathological events in the CNS. Trends in Neuroscience 19:312-318, 1996.

21. Gao H-M, Hong J-S. Critical role of microglial NADPH oxidase in rotenone-induced degeneration of dopaminergic neurons. J Neuroscience 23:6181-6187, 2002.

22. Hudome S, Palmer C, Roberts RL, Mauger D, Housman C, Towfighi J. The role of neutrophils in the production of hypoxicischemic brain injury in the neonatal rat. Pediatr Res 41:607616, 1997.

23. Kawabata K, Hagio T, Matsuoka S. The role of neutrophil elastase in acute lung injury. Eur J Pharmacol 451:1-10, 2002.

24. Lee W, Downey G. Leukocyte elastase: physiological functions and role in acute lung injury. Am J Respir Crit Care Med 164: 896-904, 2001.

25. Owen C, Campbell E. The cell biology of leukocyte-mediated proteolysis. J Leukoc Biol 1999 Feb;65(2):137-50. 65:137-150, 1999.

26. DeWitt DS, Prough DS. Traumatic cerebral vascular injury: the effects of concussive brain injury on the cerebral vasculature. $J$ Neurotrauma 20:795-825, 2003.

27. Morganti-Kossmann MC, Rancan M, Stahel PF, Kossmann T. Inflammatory response in acute traumatic brain injury: a doubleedged sword. Curr Opin Crit Care 8:101-105, 2002.

28. Rothwall N. Interleukin-1 and neuronal injury: mechanisms, modification, and therapeutic potential. Brain, Behavior, and Immunity 17:152-157, 2003.

29. Sherwood ER, Prough DS. Interleukin-8, neuroinflammation, and secondary brain injury. Crit Care Med 28:1221-1223, 2000.

30. Shohami E, Bass R, Wallach D, Yamin A, Gallily R. Inhibition of tumor necrosis factor alpha (TNFalpha) activity in rat brain is associated with cerebroprotection after closed head injury. J Cereb Blood Flow Metab 16:378-384, 1996.

31. Scherbel U, Raghupathi R, Nakamura M, Saatman KE, Trojanowski JQ, Neugebauer E, et al. Differential acute and chronic responses of tumor necrosis factor-deficient mice to experimental brain injury. Proc Natl Acad Sci U S A 96:8721-8726, 1999.

32. Toulmond S, Rothwell NJ. Interleukin-1 receptor antagonist inhibits neuronal damage caused by fluid percussion injury in the rat. Brain Res 671:261-266, 1995.

33. DeKosky ST, Styren SD, O'Malley ME, Goss JR, Kochanek P, Marion D, et al. Interleukin-1 receptor antagonist suppresses neurotrophin response in injured rat brain. Ann Neurol 39:123-127, 1996.
34. Yang $\mathrm{K}, \mathrm{Mu} \mathrm{XS}$, Hayes RL. Increased cortical nuclear factorkappa B (NF-kappa B) DNA binding activity after traumatic brain injury in rats. Neurosci Lett 197:101-104, 1995.

35. Nonaka M, Chen XH, Pierce JE, Leoni MJ, McIntosh TK, Wolf JA, et al. Prolonged activation of NF-kappaB following traumatic brain injury in rats. $J$ Neurotrauma 16:1023-1034, 1999.

36. Bell MJ, Kochanek PM, Doughty LA, Carcillo JA, Adelson PD, Clark RS, et al. Interleukin-6 and interleukin-10 in cerebrospinal fluid after severe traumatic brain injury in children. J Neurotrauma 14:451-457, 1997.

37. Bell MJ, Kochanek PM, Doughty LA, Carcillo JA, Adelson PD, Clark RS, et al. Comparison of the interleukin- 6 and interleukin-10 response in children after severe traumatic brain injury or septic shock. Acta Neurochir Suppl (Wien) 70:96-97, 1997.

38. Bajetto A, Bonavai R, S. B, G. S. Characterization of chemokines and their receptors in the central nervous system: physiopathological implications. J Neurochem. 82:1311-1329, 2002.

39. Bell MD, Taub DD, Perry VH. Overriding the brain's intrinsic resistance to leukocyte recruitment with intraparenchymal injections of recombinant chemokines. Neuroscience 74:283-292, 1996.

40. Whalen MJ, Carlos TM, Kochanek PM, Wisniewski SR, Bell MJ, Clark RS, et al. Interleukin-8 is increased in cerebrospinal fluid of children with severe head injury. Crit Care Med 28:929-934, 2000.

41. Vane JR, Botting RM. Mechanism of action of antiinflammatory drugs. Int J Tissue React 20:3-15, 1998.

42. Willard LB, Hauss-Wegrzyniak B, Danysz W, Wenk GL. The cytotoxicity of chronic neuroinflammation upon basal forebrain cholinergic neurons of rats can be attenuated by glutamatergic antagonism or cyclooxygenase-2 inhibition. Exp Brain Res 134: $58-65,2000$.

43. Dunon D, Piali L, Imhof B. To stick or not to stick: the new leukocyte homing paradigm. Curr Opin Cell Biol 8:714-723, 1996.

44. Whalen MJ, Carlos TM, Dixon CE, Schiding JK, Clark RS, Baum $\mathrm{E}$, et al. Effect of traumatic brain injury in mice deficient in intercellular adhesion molecule-1: assessment of histopathologic and functional outcome. J Neurotrauma 16:299-309, 1999.

45. Knoblach S, Faden AI. Administration of either anti-intercellular adhesion molecule-1 or a nonspecific control antibody improves recovery after traumatic brain injury in the rat. $J$ Neurotrauma 19:1039-1049, 2002.

46. Balabanov R, Goldman H, Murphy S, Pellizon G, Owen C, Rafols J, et al. Endothelial cell activation following moderate traumatic brain injury. Neurol Res 23:175-182, 2001.

47. Whalen MJ, Carlos TM, Kochanek PM, Wisniewski SR, Bell MJ, Carcillo JA, et al. Soluble adhesion molecules in CSF are increased in children with severe head injury. J Neurotrauma 15: 777-787, 1998.

48. Lawson LJ, Perry VH. The unique characteristics of inflammatory responses in mouse brain are acquired during postnatal development. Eur J Neurosci 7:1584-1595, 1995.

49. Anthony DC, Bolton SJ, Fearn S, Perry VH. Age-related effects of interleukin-1 beta on polymorphonuclear neutrophil-dependent increases in blood-brain barrier permeability in rats. Brain $120(\mathrm{Pt}$ 3):435-444, 1997

50. Anthony D, Dempster R, Fearn S, Clements J, Wells G, Perry $\mathrm{VH}$, et al. CXC chemokines generate age-related increases in neutrophil-mediated brain inflammation and blood-brain barrier breakdown. Curr Biol 8:923-926, 1998.

51. Yrjanheikki J, Tikka T, Keinanen R, Goldsteins G, Chan PH, Koistinaho J. A tetracycline derivative, minocycline, reduces inflammation and protects against focal cerebral ischemia with a wide therapeutic window. PNAS 96:13496-13500, 1999.

52. Tikka T, Fiebich B, Goldsteins G, Keinanen R, Koistinaho J. Minocycline, a tetracycline derivative, is neuroprotective against excitotoxicity by inhibiting activation and proliferation of microglia. J Neuroscience 21:2580-2588, 2001.

53. Popovic N, Schubart A, Goetz B, Zhang S, Linington C, Duncan ID. Inhibition of autoimmune encephalomyelitis by a tetracycline. Ann Neurol 51:215-223, 2002.

54. Thomas M, Le WD, Jankovic J. Minocycline and other tetracy- 
cline derivatives: a neuroprotective strategy in Parkinson's disease and Huntington's disease. Clin Neuropharmacol 26:1823, 2003.

55. Zhu S, Stavrovskaya IG, Drozda M, Kim BY, Ona V, Li M, et al. Minocycline inhibits cytochrome c release and delays progression of amyotrophic lateral sclerosis in mice. Nature 417:74-78, 2002.

56. Saccani S, Pantano S, Natoli G. p38-Dependent marking of inflammatory genes for increased NF-kappa B recruitment. Nat Immunol 3:69-75, 2002.

57. Sanchez Mejia R, Ona V, Li M, Friedlander RM. Minocycline reduces traumatic brain injury-mediated caspase-1 activation, tissue damage, and neurological dysfunction. Neurosurgery 48:1293-1298, 2001.

58. Arvin KL, Han BH, Du Y, Lin SZ, Paul SM, Holtzman DM. Minocycline markedly protects the neonatal brain against hypoxic-ischemic injury. Ann Neurol 52:54-61, 2002.

59. Fox C, Dingman A, Derugin N, Wendland MF, Manabat C, Ji S, et al. Minocycline confers early but transient protection in the immature brain following focal cerebral ischemia-reperfusion. J Cereb Blood Flow Metab 25:1138-1149, 2005.

60. Kontos HA, Wei EP. Superoxide production in experimental brain injury. $J$ Neurosurg 64:803-807, 1986.

61. Hall ED, Braughler JM. Free radicals in CNS injury. Res Publ Assoc Res Nerv Ment Dis 71:81-105, 1993.

62. Smith SL, Andrus PK, Zhang JR, Hall ED. Direct measurement of hydroxyl radicals, lipid peroxidation, and blood-brain barrier disruption following unilateral cortical impact head injury in the rat. J Neurotrauma 11:393-404., 1994.

63. Lewen A, Matz P, Chan PH. Free radical pathways in CNS injury. J Neurotrauma 17:871-890, 2000.

64. Shohami E, Beit-Yannai E, Horowitz M, Kohen R. Oxidative stress in closed-head injury: brain antioxidant capacity as an indicator of functional outcome. J Cereb Blood Flow Metab 17:1007-1019, 1997.

65. Warner DS, Sheng H, Batinic-Haberle I. Oxidants, antioxidants and the ischemic brain. J Exp Biol 207:3221-3231, 2004.

66. Lifshitz J, Sullivan PG, Hovda DA, Wieloch T, McIntosh TK. Mitochondrial damage and dysfunction in traumatic brain injury. Mitochondrion 4:705-713, 2004.

67. Dietrich WD, Chatzipanteli K, Vitarbo E, Wada K, Kinoshita K. The role of inflammatory processes in the pathophysiology and treatment of brain and spinal cord trauma. Acta Neurochir Suppl 89:69-74, 2004.

68. Feuerstein GZ, Wang X, Barone FC. Inflammatory gene expression in cerebral ischemia and trauma. Potential new therapeutic targets. Ann N Y Acad Sci 825:179-193, 1997.

69. Floyd RA, Carney JM. Age influence on oxidative events during brain ischemia/reperfusion. Arch Gerontol Geriatr 12:155-177, 1991.

70. Bayir H, Kagan VE, Tyurina YY, Tyurin V, Ruppel RA, Adelson $\mathrm{PD}$, et al. Assessment of antioxidant reserves and oxidative stress in cerebrospinal fluid after severe traumatic brain injury in infants and children. Pediatr Res 51:571-578, 2002.

71. Sheldon RA, Jiang X, Francisco C, Christen S, Vexler ZS, Tauber $\mathrm{MG}$, et al. Manipulation of antioxidant pathways in neonatal murine brain. Pediatr Res 56:656-662, 2004.

72. Natale JE, Knight JB, Cheng Y, Rome JE, Gallo V. Metallothionein I and II mitigate age-dependent secondary brain injury. J Neurosci Res 78:303-314, 2004.

73. Mavelli I, Rigo A, Federico R, Ciriolo MR, Rotilio G. Superoxide dismutase, glutathione peroxidase and catalase in developing rat brain. Biochem J 204:535-540, 1982.

74. Mikawa S, Kinouchi H, Kamii H, Gobbel GT, Chen SF, Carlson $\mathrm{E}$, et al. Attenuation of acute and chronic damage following traumatic brain injury in copper, zinc-superoxide dismutase transgenic mice. J Neurosurg 85:885-891, 1996.

75. McIntosh TK, Juhler M, Wieloch T. Novel pharmacologic strategies in the treatment of experimental traumatic brain injury: 1998. J Neurotrauma 15:731-769, 1998.

76. Kinouchi H, Epstein CJ, Mizui T, Carlson E, Chen SF, Chan PH. Attenuation of focal cerebral ischemic injury in transgenic mice overexpressing CuZn superoxide dismutase. Proc Natl Acad Sci U S A 88:11158-11162, 1991.

77. Ditelberg JS, Sheldon RA, Epstein CJ, Ferriero DM. Brain injury after perinatal hypoxia-ischemia is exacerbated in copper/zinc superoxide dismutase transgenic mice. Pediatr Res 39:204-208, 1996.

78. Fullerton HJ, Ditelberg JS, Chen SF, Sarco DP, Chan PH, Epstein $\mathrm{CJ}$, et al. Copper/zinc superoxide dismutase transgenic brain accumulates hydrogen peroxide after perinatal hypoxia ischemia. Ann Neurol 44:357-364, 1998.

79. Mischel RE, Kim YS, Sheldon RA, Ferriero DM. Hydrogen peroxide is selectively toxic to immature murine neurons in vitro. Neurosci Lett 231:17-20, 1997.

80. Lewen A, Fujimura M, Sugawara T, Matz P, Copin JC, Chan PH. Oxidative stress-dependent release of mitochondrial cytochrome c after traumatic brain injury. J Cereb Blood Flow Metab 21: 914-920, 2001.

81. Sheng H, Bart RD, Oury TD, Pearlstein RD, Crapo JD, Warner DS. Mice overexpressing extracellular superoxide dismutase have increased resistance to focal cerebral ischemia. Neuroscience 88: 185-191, 1999.

82. Sheng H, Kudo M, Mackensen GB, Pearlstein RD, Crapo JD, Warner DS. Mice overexpressing extracellular superoxide dismutase have increased resistance to global cerebral ischemia. Exp Neurol 163:392-398, 2000.

83. Sheng H, Brady TC, Pearlstein RD, Crapo JD, Warner DS. Extracellular superoxide dismutase deficiency worsens outcome from focal cerebral ischemia in the mouse. Neurosci Lett 267: 13-16, 1999.

84. Hamm RJ, Temple MD, Pike BR, Ellis EF. The effect of postinjury administration of polyethylene glycol-conjugated superoxide dismutase (pegorgotein, Dismutec) or lidocaine on behavioral function following fluid-percussion brain injury in rats. J Neurotrauma 13:325-332, 1996.

85. Yunoki M, Kawauchi M, Ukita N, Noguchi Y, Nishio S, Ono Y, et al. Effects of lecithinized superoxide dismutase on traumatic brain injury in rats. J Neurotrauma 14:739-746, 1997.

86. Yunoki M, Kawauchi M, Ukita N, Sugiura T, Ohmoto T. Effects of lecithinized superoxide dismutase on neuronal cell loss in CA3 hippocampus after traumatic brain injury in rats. Surg Neurol 59:156-160; discussion 160-151, 2003.

87. Kesner RP, Lee I, Gilbert P. A behavioral assessment of hippocampal function based on a subregional analysis. Rev Neurosci 15:333-351, 2004.

88. Marklund SL, Westman NG, Lundgren E, Roos G. Copper- and zinc-containing superoxide dismutase, manganese-containing superoxide dismutase, catalase, and glutathione peroxidase in normal and neoplastic human cell lines and normal human tissues. Cancer Res 42:1955-1961, 1982.

89. Fan P, Yamauchi T, Noble LJ, Ferriero DM. Age-dependent differences in glutathione peroxidase activity after traumatic brain injury. J Neurotrauma 20:437-445, 2003.

90. Royo NC, Shimizu S, Schouten JW, Stover JF, McIntosh TK. Pharmacology of traumatic brain injury. Curr Opin Pharmacol $3: 27-32,2003$.

91. Marklund N, Clausen F, McIntosh TK, Hillered L. Free radical scavenger posttreatment improves functional and morphological outcome after fluid percussion injury in the rat. $J$ Neurotrauma 18:821-832, 2001.

92. Hall ED, Yonkers PA, McCall JM, Braughler JM. Effects of the 21-aminosteroid U74006F on experimental head injury in mice. J Neurosurg 68:456-461, 1988.

93. McIntosh TK, Thomas M, Smith D, Banbury M. The novel 21-aminosteroid U74006F attenuates cerebral edema and improves survival after brain injury in the rat. $J$ Neurotrauma 9:3346, 1992.

94. Sanada T, Nakamura T, Nishimura MC, Isayama K, Pitts LH. Effect of U74006F on neurologic function and brain edema after fluid percussion injury in rats. J Neurotrauma 10:65-71, 1993.

95. Mathew P, Bullock R, Teasdale G, McCulloch J. Changes in local microvascular permeability and in the effect of intervention with 21-aminosteroid (Tirilazad) in a new experimental model of focal cortical injury in the rat. J Neurotrauma 13:465-472, 1996. 
96. Wei EP, Kontos HA, Dietrich WD, Povlishock JT, Ellis EF. Inhibition by free radical scavengers and by cyclooxygenase inhibitors of pial arteriolar abnormalities from concussive brain injury in cats. Circ Res 48:95-103, 1981.

97. Hall ED. Beneficial effects of acute intravenous ibuprofen on neurologic recovery of head-injured mice: comparison of cyclooxygenase inhibition with inhibition of thromboxane A2 synthetase or 5-lipoxygenase. Cent Nerv Syst Trauma 2:75-83, 1985.

98. Kim HJ, Levasseur JE, Patterson JL, Jr., Jackson GF, Madge GE, Povlishock JT, et al. Effect of indomethacin pretreatment on acute mortality in experimental brain injury. $J$ Neurosurg 71:565-572, 1989.

99. Jafarian-Tehrani M, Louin G, Royo NC, Besson VC, Bohme GA, Plotkine M, et al. $1400 \mathrm{~W}$, a potent selective inducible NOS inhibitor, improves histopathological outcome following traumatic brain injury in rats. Nitric Oxide 12:61-69, 2005.

100. Clifton GL, Lyeth BG, Jenkins LW, Taft WC, DeLorenzo RJ, Hayes RL. Effect of D, alpha-tocopheryl succinate and polyethylene glycol on performance tests after fluid percussion brain injury. J Neurotrauma 6:71-81, 1989.

101. Inci S, Ozcan OE, Kilinc K. Time-level relationship for lipid peroxidation and the protective effect of alpha-tocopherol in experimental mild and severe brain injury. Neurosurgery 43:330335; discussion 335-336, 1998.

102. Beit-Yannai E, Zhang R, Trembovler V, Samuni A, Shohami E. Cerebroprotective effect of stable nitroxide radicals in closed head injury in the rat. Brain Res 717:22-28, 1996.

103. Zhang R, Shohami E, Beit-Yannai E, Bass R, Trembovler V, Samuni A. Mechanism of brain protection by nitroxide radicals in experimental model of closed-head injury. Free Radic Biol Med 24:332-340, 1998.

104. Sarrafzadeh AS, Thomale UW, Kroppenstedt SN, Unterberg AW. Neuroprotective effect of melatonin on cortical impact injury in the rat. Acta Neurochir (Wien) 142:1293-1299, 2000.

105. Ozdemir D, Tugyan K, Uysal N, Sonmez U, Sonmez A, Acikgoz $\mathrm{O}$, et al. Protective effect of melatonin against head traumainduced hippocampal damage and spatial memory deficits in immature rats. Neurosci Lett 385:234-239, 2005.

106. Shohami E, Novikov M, Bass R. Long-term effect of HU-211, a novel non-competitive NMDA antagonist, on motor and memory functions after closed head injury in the rat. Brain Res 674:5562, 1995.

107. Nadler V, Biegon A, Beit-Yannai E, Adamchik J, Shohami E. $45 \mathrm{Ca}$ accumulation in rat brain after closed head injury; attenuation by the novel neuroprotective agent HU-211. Brain Res 685:1-11, 1995.

108. Aoyama N, Katayama Y, Kawamata T, Maeda T, Mori T, Yamamoto T, et al. Effects of antioxidant, OPC-14117, on secondary cellular damage and behavioral deficits following cortical contusion in the rat. Brain Res 934:117-124, 2002.

109. Xiong Y, Peterson PL, Muizelaar JP, Lee CP. Amelioration of mitochondrial function by a novel antioxidant U-101033E following traumatic brain injury in rats. J Neurotrauma 14:907-917, 1997.

110. Wada K, Alonso OF, Busto R, Panetta J, Clemens JA, Ginsberg $\mathrm{MD}$, et al. Early treatment with a novel inhibitor of lipid peroxidation (LY341122) improves histopathological outcome after moderate fluid percussion brain injury in rats. Neurosurgery 45: 601-608, 1999.

111. Hall ED, Andrus PK, Smith SL, Fleck TJ, Scherch HM, Lutzke BS, et al. Pyrrolopyrimidines: novel brain-penetrating antioxidants with neuroprotective activity in brain injury and ischemia models. J Pharmacol Exp Ther 281:895-904, 1997.

112. Muizelaar JP, Marmarou A, Young HF, Choi SC, Wolf A, Schneider RL, et al. Improving the outcome of severe head injury with the oxygen radical scavenger polyethylene glycol-conjugated superoxide dismutase: a phase II trial. J Neurosurg 78:375382, 1993.

113. Young B, Runge JW, Waxman KS, Harrington T, Wilberger J, Muizelaar JP, et al. Effects of pegorgotein on neurologic outcome of patients with severe head injury. A multicenter, randomized controlled trial. Jama 276:538-543, 1996.
114. Marshall LF, Maas AI, Marshall SB, Bricolo A, Fearnside M, Iannotti $\mathrm{F}$, et al. A multicenter trial on the efficacy of using tirilazad mesylate in cases of head injury. J Neurosurg 89:519$525,1998$.

115. Knoller N, Levi L, Shoshan I, Reichenthal E, Razon N, Rappaport $\mathrm{ZH}$, et al. Dexanabinol (HU-211) in the treatment of severe closed head injury: a randomized, placebo-controlled, phase II clinical trial. Crit Care Med 30:548-554, 2002.

116. Yamaguchi T, Sano K, Takakura K, Saito I, Shinohara Y, Asano $\mathrm{T}$, et al. Ebselen in acute ischemic stroke: a placebo-controlled, double-blind clinical trial. Ebselen Study Group. Stroke 29:1217, 1998.

117. Saito I, Asano T, Sano K, Takakura K, Abe H, Yoshimoto T, et al. Neuroprotective effect of an antioxidant, ebselen, in patients with delayed neurological deficits after aneurysmal subarachnoid hemorrhage. Neurosurgery 42:269-277; discussion 277-268, 1998.

118. Ogawa A, Yoshimoto T, Kikuchi H, Sano K, Saito I, Yamaguchi $\mathrm{T}$, et al. Ebselen in acute middle cerebral artery occlusion: a placebo-controlled, double-blind clinical trial. Cerebrovasc Dis 9:112-118, 1999.

119. Chang EF, Claus CP, Vreman HJ, Wong RJ, Noble-Haeusslein LJ. Heme regulation in traumatic brain injury: relevance to the adult and developing brain. J Cereb Blood Flow Metab, 2005

120. Connor JR, Menzies SL, Burdo JR, Boyer PJ. Iron and iron management proteins in neurobiology. Pediatr Neurol 25:118129, 2001.

121. Roskams AJ, Connor JR. Iron, transferrin, and ferritin in the rat brain during development and aging. J Neurochem 63:709-716, 1994.

122. Berger HM, Mumby S, Gutteridge JM. Ferrous ions detected in iron-overloaded cord blood plasma from preterm and term babies: implications for oxidative stress. Free Radic Res 22:555-559, 1995.

123. Gutteridge JM, Mumby S, Koizumi M, Taniguchi N. "Free" iron in neonatal plasma activates aconitase: evidence for biologically reactive iron. Biochem Biophys Res Commun 229:806-809, 1996.

124. Gutteridge JM. Ferrous ions detected in cerebrospinal fluid by using bleomycin and DNA damage. Clin Sci (Lond) 82:315-320, 1992.

125. Dietrich RB, Bradley WG, Jr. Iron accumulation in the basal ganglia following severe ischemic-anoxic insults in children. $R a$ diology 168:203-206, 1988.

126. Cheepsunthorn P, Palmer C, Menzies S, Roberts RL, Connor JR. Hypoxic/ischemic insult alters ferritin expression and myelination in neonatal rat brains. J Comp Neurol 431:382-396, 2001.

127. Palmer C, Menzies SL, Roberts RL, Pavlick G, Connor JR. Changes in iron histochemistry after hypoxic-ischemic brain injury in the neonatal rat. J Neurosci Res 56:60-71, 1999.

128. Kondo Y, Ogawa N, Asanuma M, Ota Z, Mori A. Regional differences in late-onset iron deposition, ferritin, transferrin, astrocyte proliferation, and microglial activation after transient forebrain ischemia in rat brain. $J$ Cereb Blood Flow Metab 15: 216-226, 1995

129. Fredriksson A, Schroder N, Eriksson P, Izquierdo I, Archer T. Neonatal iron exposure induces neurobehavioural dysfunctions in adult mice. Toxicol Appl Pharmacol 159:25-30, 1999.

130. Connor JR, Menzies SL. Relationship of iron to oligodendrocytes and myelination. Glia 17:83-93, 1996.

131. Connor JR, Pavlick G, Karli D, Menzies SL, Palmer C. A histochemical study of iron-positive cells in the developing rat brain. J Comp Neurol 355:111-123, 1995.

132. Ikeda Y, Ikeda K, Long DM. Comparative study of different iron-chelating agents in cold-induced brain edema. Neurosurgery 24:820-824, 1989

133. Regan RF, Rogers B. Delayed treatment of hemoglobin neurotoxicity. J Neurotrauma 20:111-120, 2003.

134. Bergeron M, Gidday JM, Yu AY, Semenza GL, Ferriero DM, Sharp FR. Role of hypoxia-inducible factor-1 in hypoxia-induced ischemic tolerance in neonatal rat brain. Ann Neurol 48:285-296, 2000.

135. Hamrick SE, McQuillen PS, Jiang X, Mu D, Madan A, Ferriero 
DM. A role for hypoxia-inducible factor-1alpha in desferoxamine neuroprotection. Neurosci Lett 379:96-100, 2005.

136. Long DA, Ghosh K, Moore AN, Dixon CE, Dash PK. Deferoxamine improves spatial memory performance following experimental brain injury in rats. Brain Res 717:109-117, 1996.

137. Panter SS, Braughler JM, Hall ED. Dextran-coupled deferoxamine improves outcome in a murine model of head injury. J Neurotrauma 9:47-53, 1992.

138. Nakamura T, Keep RF, Hua Y, Schallert T, Hoff JT, Xi G. Deferoxamine-induced attenuation of brain edema and neurological deficits in a rat model of intracerebral hemorrhage. J Neurosurg 100:672-678, 2004.

139. Groenendaal F, Shadid M, McGowan JE, Mishra OP, van Bel F. Effects of deferoxamine, a chelator of free iron, on $\mathrm{NA}(+)$, $\mathrm{K}(+)$-ATPase activity of cortical brain cell membrane during early reperfusion after hypoxia-ischemia in newborn lambs. $\mathrm{Pe}$ diatr Res 48:560-564, 2000.

140. Peeters-Scholte C, Braun K, Koster J, Kops N, Blomgren K, Buonocore G, et al. Effects of allopurinol and deferoxamine on reperfusion injury of the brain in newborn piglets after neonatal hypoxia-ischemia. Pediatr Res 54:516-522, 2003.

141. Pettus EH, Wright DW, Stein DG, Hoffman SW. Progesterone treatment inhibits the inflammatory agents that accompany traumatic brain injury. Brain Res 1049:112-119, 2005.
142. He J, Evans CO, Hoffman SW, Oyesiku NM, Stein DG. Progesterone and allopregnanolone reduce inflammatory cytokines after traumatic brain injury. Exp Neurol 189:404-412, 2004.

143. Truettner JS, Suzuki T, Dietrich WD. The effect of therapeutic hypothermia on the expression of inflammatory response genes following moderate traumatic brain injury in the rat. Brain Res Mol Brain Res 138:124-134, 2005.

144. Lynch JR, Wang H, Mace B, Leinenweber S, Warner DS, Bennett $\mathrm{ER}$, et al. A novel therapeutic derived from apolipoprotein $\mathrm{E}$ reduces brain inflammation and improves outcome after closed head injury. Exp Neurol 192:109-116, 2005.

145. Marklund N, Keck C, Hoover R, Soltesz K, Millard M, LeBold D, et al. Administration of monoclonal antibodies neutralizing the inflammatory mediators tumor necrosis factor alpha and interleukin -6 does not attenuate acute behavioral deficits following experimental traumatic brain injury in the rat. Restor Neurol Neurosci 23:31-42, 2005.

146. Gopez JJ, Yue H, Vasudevan R, Malik AS, Fogelsanger LN, Lewis $\mathrm{S}$, et al. Cyclooxygenase-2-specific inhibitor improves functional outcomes, provides neuroprotection, and reduces inflammation in a rat model of traumatic brain injury. Neurosurgery 56:590-604, 2005. 